\title{
High School Pupils' Relationships with Their Parents, Schoolmates, and Friends, and Health-Related Risk Behaviors
}

\author{
Oana Codruta Miloicov \\ Bacean (iD) \\ Ovidiu Fira-Mladinescu (iD) ${ }^{2}$ \\ Salomeia Putnoky' \\ loana Tuta Sas id \\ Petrescu Cristina' \\ Radu Bagiu' \\ Iulia Cristina Bagiu ${ }^{3}$ \\ Oana Suciu' \\ Corneluta Fira-Mladinescu (D) ' \\ Brigitha Vlaicu' \\ 'Discipline of Hygiene, Department 14 \\ Microbiology, "Victor Babes" University \\ of Medicine and Pharmacy Timisoara, \\ Center for Studies in Preventive \\ Medicine, Timisoara, Timis, Romania; \\ 2Pneumology Discipline, Department \\ I3th Infectious Diseases, "Victor Babes" \\ University of Medicine and Pharmacy \\ Timisoara, Center for Studies in \\ Preventive Medicine, Timisoara, Timis, \\ Romania; ${ }^{3}$ Discipline of Microbiology, \\ Department 14 Microbiology, "Victor \\ Babes" University of Medicine and \\ Pharmacy Timisoara, Center for Studies \\ in Preventive Medicine, Timisoara, Timis, \\ Romania
}

Correspondence: Oana Codruta Miloicov Bacean

Dumbravita, str Fiziii, nr.8, Timis County, Romania

Tel +40745170879

Email baceano@gmail.com
Purpose: The aims of this study were to evaluate high school pupils' relationships with their parents, schoolmates, and friends, and the presence of health-related risk behaviors among the family members and friends on the pupils' smoking and binge drinking status.

Materials and Methods: The study was a cross-sectional population-based study that involved a questionnaire, and the sample involved 2908 pupils at high schools in Timis county, Romania. In our study, the following factors related to family members and friends and the living environment were identified. First, there were issues with the relationships with parents among some pupils, with $23.2 \%$ being neither satisfied nor unsatisfied and $4.9 \%$ being unsatisfied. Second, there were also issues regarding some pupils' satisfaction with the financial situation of their family, with $21.8 \%$ being neither satisfied nor unsatisfied and $16.4 \%$ being unsatisfied. An odds ratio (OR) is a statistic that quantifies the strength of the association between two events.

Results: There were 1495 (51.5\%) girls and 1407 (48.5\%) boys aged 14-20 years, and $79.2 \%$ came from organized families. Among the pupils, $71.1 \%$ reported that they were satisfied with their relationship with their parents, while $4.9 \%$ were unsatisfied. Additionally, $46.2 \%$ were satisfied with the financial status of their families, while $16.4 \%$ were unsatisfied. Moreover, 59.2\% were satisfied with their relationship with their schoolmates and $80.2 \%$ were satisfied with their relationship with their friends, while only $1.8 \%$ were unsatisfied with their relationship with their friends. The logistic regression model of the pupils' smoking status identified two moderate predictive factors: this was defined " $>1$ " friends who smoke (odds ratio $[\mathrm{OR}]=2.875)$ and smoking status of siblings $(\mathrm{OR}=2.222)$. The major predictive factor in the logistic regression model of occasional alcohol consumption in high quantities by pupils was male gender $(\mathrm{OR}=5.148)$.

Conclusion: The predictive model of pupils' smoking status identified the following moderate predictors: high number of friends who smoke and smoking status of siblings. The major predictor in the model of occasional alcohol consumption in high quantities by pupils was male gender.

Keywords: teenagers, pupils, family, entourage, health risk

\section{Introduction}

From a public health perspective, risk factors that trigger health-related risk behaviors as an individual grows up and matures are dynamic. The predictive value of the risk factors is modified based both on the moment when they start acting on the individual's development and on the social context. Risk factors can be related to the individual, the environment, or the individual's ability to respond to the 
environment's requirements. Some factors become obvious during childhood or even earlier, while others only appear during the teenage years. Certain factors decrease in importance as the individual matures, whereas the importance of others is maintained throughout the individual's entire life. Some factors can act as risk factors during a specific stage of life. ${ }^{1}$ The presence of a combination of risk factors can be synergic. It is considered that risk factors come in groups, rather than being present in isolation. ${ }^{2}$

Protective factors that prevent the occurrence of risk factors represent the absence of risk. ${ }^{3}$ This type of framework places risk factors and protective factors in complete opposition. For example, good relationships between parents and children can be considered as protective factors as they are the opposite of poor relationships between parents and children, which represents a well-known risk factor. A low family income is a risk factor for violence, but a family environment with supportive relationships between parents and children is a protective factor. Although supportive relationships do not improve the economic status of the family, they compensate for the adverse effects of poverty on children. ${ }^{4}$

Risk factors and protective factors regarding a teenager's behaviors can be grouped into factors related to the individual, family, school environment, group of friends, or the community where the teenager lives. They can vary during the three stages of human development they can interact, and they can have cumulative effects. ${ }^{5,6}$

From the perspective of human development, puberty is accompanied by major physical and emotional changes that can influence a young person's relationships and his/ her way of interacting with his/her peers. The transition from adolescence creates independence from one's parents and necessitates expressing one's own values, personal identity, and sexual identity, and the development of the skills and competences necessary for normal functioning in adult society. To become independent, young people need to renegotiate their parents' rules and degree of monitoring, which can generate conflicts and alienation from the parents. At the same time, the young person's social networks are expanding, and the relationships with friends and adults in various social contexts mean that social relationships can match or even surpass the importance of the relationships with their parents. ${ }^{7}$ The process of adaptation to all these modifications of relationships, social contexts, and performance expectations an generate stress, feelings of rejection and anger, and experiences failure. Young people can be attracted to violent behavior because it can provide them with ways to manifest their independence in the adult world, gain schoolmates' attention and admiration, compensate for their own limited personal competences, and/or respond to the limited opportunities for success in school or in the community. Good relationships with parents during childhood can contribute to a successful transition during adolescence. ${ }^{8}$

We thought of starting the research in Timis county, a smaller area, and then to extend it to other counties in order to find out if there are any differences. Timis county is one of the most developed parts of our country, therefore significant aspects could come out from this point.

If we consider connection, competence and control, three major aspects that psychologist take into consideration when behavior changes happen, even as adults, not only in childhood, this leads to finding a balance between the three items, in order to have a balanced child or even adult.

The aims of this study were to evaluate high school pupils' relationships with their parents, schoolmates, and friends, and to assess the influence of the presence of health-related risk behaviors among the family members and friends on the pupils' smoking and binge drinking status.

\section{Materials and Methods}

The research methods consist of questionnaires and sample selection. $^{9-11}$

This study is a cross-sectional population-based study that involved a questionnaire that included questions on the degree of satisfaction with relationships with family, schoolmates, and friends and the presence of health-related risk behaviors among family members and friends. ${ }^{9-11}$

The questionnaire was filled in through face to face interview with written approval from the pupils' schools. We obtained parental informed consent from each of the pupils' parents, for participants under the age of 18 , before their participation in the study, and their individual rights, including anonymity and confidentiality, were ensured. The research was conducted in accordance with the Declaration of Helsinki. The research was approved by Commission for Scientific Research Ethics of "V. Babes" University of Medicine and Pharmacy Timisoara (NO 02/ 16.01.2015-

Conclusion: The commission considers that the criteria of medical ethics are met, from the perspective of both 
general and punctual principles related to biomedical research on human subjects and that it respects the rights of vulnerable persons).

The study involved 2908 pupils from high schools in Timis county, Romania. There were 1495 (51.5\%) girls and $1407(48.5 \%)$ boys. The participants were all teenagers aged $14(0.4 \%)$ to $20(0.6 \%)$ years, with most being aged $16(830,28.5 \%)$ and $17(825,28.4 \%)$ years.

Data analysis and interpretation was performed using PASW Statistics 18 (formerly SPSS Statistics 18). $\mathrm{P}<0.05$ was considered to be statistically significant, and $\mathrm{P}<0.01$ was considered to be highly statistically significant. The data were analyzed using the chi-square test, the MannWhitney $U$-test, the Kruskal-Wallis test, and Pearson and Kendall correlation analyses. ${ }^{12,13}$

\section{Results}

\section{Family Organization}

Regarding the family organization, $79.2 \%$ (2285) of the pupils came from an organized family, $13.2 \%$ (381) came from a disorganized family, and 7.6\% (220) came from a reorganized family (Table 1).

\section{Satisfaction with Relationship with Parents}

In terms of their relationship with parents, $71.1 \%$ (2050) of the participants reported being satisfied, with a consistent gender distribution. However, 23.2\% (669) reported that they were neither satisfied nor unsatisfied with their relationship with their parents, and 4.9\% (141) were unsatisfied (Table 2).

To compare the degree of satisfaction with relationships with parents between the two genders, we excluded the pupils without parents. Boys were significantly more satisfied with their relationship with their parents than girls $(\mathrm{U}=919215.5, \mathrm{z}=-5.88, \mathrm{P}<0.001)$.
Table 2 Distribution of Pupils Based on Degree of Satisfaction with Their Relationship with Their Parents

\begin{tabular}{|c|c|c|c|c|}
\hline & & \multicolumn{2}{|c|}{ Gender } & \multirow{2}{*}{ Total } \\
\hline & & Female & Male & \\
\hline Satisfied & $\begin{array}{l}\text { Number } \\
\%\end{array}$ & $\begin{array}{l}989 \\
34.3 \%\end{array}$ & $\begin{array}{l}1061 \\
36.8 \%\end{array}$ & $\begin{array}{l}2050 \\
71.1 \%\end{array}$ \\
\hline $\begin{array}{l}\text { Neither satisfied nor } \\
\text { unsatisfied }\end{array}$ & $\begin{array}{l}\text { Number } \\
\%\end{array}$ & $\begin{array}{l}390 \\
13.5 \%\end{array}$ & $\begin{array}{l}279 \\
9.7 \%\end{array}$ & $\begin{array}{l}669 \\
23.2 \%\end{array}$ \\
\hline Unsatisfied & $\begin{array}{l}\text { Number } \\
\%\end{array}$ & $\begin{array}{l}96 \\
3.3 \%\end{array}$ & $\begin{array}{l}45 \\
1.6 \%\end{array}$ & $\begin{array}{l}14 \mid \\
4.9 \%\end{array}$ \\
\hline I have no parents & $\begin{array}{l}\text { Number } \\
\%\end{array}$ & $\begin{array}{l}14 \\
0.5 \%\end{array}$ & $\begin{array}{l}11 \\
0.4 \%\end{array}$ & $\begin{array}{l}25 \\
0.9 \%\end{array}$ \\
\hline Total & $\begin{array}{l}\text { Number } \\
\%\end{array}$ & $\begin{array}{l}1489 \\
51.6 \%\end{array}$ & $\begin{array}{l}1396 \\
48.4 \%\end{array}$ & $\begin{array}{l}2885 \\
100.0 \%\end{array}$ \\
\hline
\end{tabular}

\section{Satisfaction with Financial Status of Family}

Almost half of the teenagers, $46.2 \%$ (1326), reported that they were satisfied with the financial status of their families, while $21.8 \%$ (626) reported being neither satisfied nor unsatisfied and $16.4 \%$ (471) reported that the financial status of their family does not satisfy them (Table 3).

Girls were significantly more unsatisfied with the financial status of their family than boys $(U=890059, z=$ $-6.71, \mathrm{P}<0.001)$.

\section{Satisfaction with Relationship with Schoolmates}

The relationships with schoolmates were good, with $59.2 \%$ (1631) of pupils reporting that they were satisfied with the relationship with their schoolmates. Only 7.7\% (211) were not satisfied with their relationship with their schoolmates (Table 4).

Boys were significantly more satisfied with their relationship with their schoolmates than girls $(\mathrm{U}=822383, \mathrm{z}=$ $-6.90, \mathrm{P}<0.001)$.

Table I Distribution of Pupils Based on Family Organization

\begin{tabular}{|l|l|l|l|l|}
\hline Type of Family Organization & Frequency & Percentage & Valid Percentage & Cumulative Percentage \\
\hline Organized & 2285 & 78.6 & 79.2 & 79.2 \\
Reorganized & 220 & 7.6 & 7.6 & 86.8 \\
Disorganized & 381 & 13.1 & 13.2 & 100.0 \\
Total & 2886 & 99.2 & 100.0 & \\
Missing data & 22 & 0.8 & & \\
Total & 2908 & 100.0 & & \\
\hline
\end{tabular}


Table 3 Distribution of Pupils Based on Degree of Satisfaction with the Financial Status of Their Family

\begin{tabular}{|c|c|c|c|c|}
\hline \multirow{2}{*}{\multicolumn{2}{|c|}{$\begin{array}{l}\text { How Satisfied are You with the } \\
\text { Financial Status of Your Family? }\end{array}$}} & \multicolumn{2}{|c|}{ Gender } & \multirow{3}{*}{$\begin{array}{l}\text { Total } \\
450 \\
15.7 \%\end{array}$} \\
\hline & & \multirow{2}{*}{$\begin{array}{l}\text { Female } \\
193 \\
6.7 \%\end{array}$} & \multirow{2}{*}{$\begin{array}{l}\text { Male } \\
257 \\
8.9 \%\end{array}$} & \\
\hline Very satisfied & $\begin{array}{l}\text { Number } \\
\%\end{array}$ & & & \\
\hline Satisfied & $\begin{array}{l}\text { Number } \\
\%\end{array}$ & $\begin{array}{l}650 \\
22.6 \%\end{array}$ & $\begin{array}{l}676 \\
23.5 \%\end{array}$ & $\begin{array}{l}1326 \\
46.2 \%\end{array}$ \\
\hline $\begin{array}{l}\text { Neither satisfied nor } \\
\text { unsatisfied }\end{array}$ & $\begin{array}{l}\text { Number } \\
\%\end{array}$ & $\begin{array}{l}343 \\
11.9 \%\end{array}$ & $\begin{array}{l}283 \\
9.9 \%\end{array}$ & $\begin{array}{l}626 \\
21.8 \%\end{array}$ \\
\hline Not very satisfied & $\begin{array}{l}\text { Number } \\
\%\end{array}$ & $\begin{array}{l}250 \\
8.7 \%\end{array}$ & $\begin{array}{l}136 \\
4.7 \%\end{array}$ & $\begin{array}{l}386 \\
13.4 \%\end{array}$ \\
\hline Not satisfied & $\begin{array}{l}\text { Number } \\
\%\end{array}$ & $\begin{array}{l}51 \\
1.8 \%\end{array}$ & $\begin{array}{l}34 \\
1.2 \%\end{array}$ & $\begin{array}{l}85 \\
3.0 \%\end{array}$ \\
\hline Total & $\begin{array}{l}\text { Number } \\
\%\end{array}$ & $\begin{array}{l}1487 \\
51.8 \%\end{array}$ & $\begin{array}{l}1386 \\
48.2 \%\end{array}$ & $\begin{array}{l}2873 \\
100.0 \%\end{array}$ \\
\hline
\end{tabular}

Table 4 Distribution of Pupils Based on Degree of Satisfaction with Their Relationship with Schoolmates

\begin{tabular}{|l|l|l|l|l|}
\hline \multirow{2}{*}{$\begin{array}{l}\text { How Satisfied are You with Your } \\
\text { Relationship with Schoolmates? }\end{array}$} & \multicolumn{2}{|c|}{ Gender } & \multirow{2}{*}{ Total } \\
\cline { 3 - 4 } \multicolumn{2}{|l|}{} & Female & Male & \\
\hline Satisfied & $\begin{array}{l}\text { Number } \\
\%\end{array}$ & $\begin{array}{l}765 \\
27.7 \%\end{array}$ & $\begin{array}{l}866 \\
31.4 \%\end{array}$ & $\begin{array}{l}1631 \\
59.2 \%\end{array}$ \\
\hline $\begin{array}{l}\text { Neither satisfied nor } \\
\text { unsatisfied }\end{array}$ & $\begin{array}{l}\text { Number } \\
\%\end{array}$ & $\begin{array}{l}559 \\
20.3 \%\end{array}$ & $\begin{array}{l}356 \\
12.9 \%\end{array}$ & $\begin{array}{l}915 \\
33.2 \%\end{array}$ \\
\hline Not satisfied & $\begin{array}{l}\text { Number } \\
\%\end{array}$ & $\begin{array}{l}125 \\
4.5 \%\end{array}$ & $\begin{array}{l}86 \\
3.1 \%\end{array}$ & $\begin{array}{l}211 \\
7.7 \%\end{array}$ \\
\hline Total & $\begin{array}{l}\text { Number } \\
\%\end{array}$ & $\mathbf{1 4 4 9}$ & $\mathbf{1 3 0 8}$ & $\mathbf{2 7 5 7}$ \\
& $\mathbf{5 2 . 6 \%}$ & $\mathbf{4 7 . 4 \%}$ & $\mathbf{1 0 0 . 0 \%}$ \\
\hline
\end{tabular}

\section{Satisfaction with Relationship with Friends}

Regarding relationships with friends, 80.2\% (2209) were satisfied, while $16.4 \%$ were neither satisfied nor satisfied and 1.8\% (50) were unsatisfied (Table 5).

To compare the satisfaction with relationships with friends between the two genders, we excluded pupils who reported having no friends. Boys were significantly more satisfied with their relationship with their friends than girls $(\mathrm{U}=849204, \mathrm{z}=-4.94, \mathrm{P}<0.001)$. For both girls and boys, relationships with friends generated significantly more satisfaction than relationships with schoolmates $(\mathrm{P}<0.001)$.
Table 5 Distribution of Pupils Based on Degree of Satisfaction with Their Relationship with Friends

\begin{tabular}{|c|c|c|c|c|}
\hline \multirow{2}{*}{\multicolumn{2}{|c|}{$\begin{array}{l}\text { How Satisfied are You with Your } \\
\text { Relationship with Current } \\
\text { Friends? }\end{array}$}} & \multicolumn{2}{|l|}{ Gender } & \multirow{3}{*}{$\begin{array}{l}\text { Total } \\
2209\end{array}$} \\
\hline & & \multirow{3}{*}{$\begin{array}{l}\text { Female } \\
1108 \\
40.2 \%\end{array}$} & \multirow{3}{*}{$\begin{array}{l}\text { Male } \\
1101 \\
40.0 \%\end{array}$} & \\
\hline Satisfied & Number & & & \\
\hline & & & & $80.2 \%$ \\
\hline Neither satisfied nor & Number & 289 & 164 & 453 \\
\hline unsatisfied & $\%$ & $10.5 \%$ & $6.0 \%$ & $16.4 \%$ \\
\hline \multirow[t]{2}{*}{ Not satisfied } & Number & 26 & 24 & 50 \\
\hline & $\%$ & $0.9 \%$ & $0.9 \%$ & $1.8 \%$ \\
\hline \multirow[t]{2}{*}{ I have no friends } & Number & 24 & 18 & 42 \\
\hline & & $0.9 \%$ & $0.7 \%$ & $1.5 \%$ \\
\hline \multirow[t]{2}{*}{ Total } & Number & 1447 & 1307 & 2754 \\
\hline & $\%$ & $52.5 \%$ & $47.5 \%$ & $100.0 \%$ \\
\hline
\end{tabular}

\section{Predictive Models of Risk Among Pupils}

The logistic regression analysis of the pupils' smoking status indicated that the strongest predictor was having a high number of friends who smoke, that is, pupils with a high number of friends who smoke were 2.9 times more likely to smoke (odds ratio $[\mathrm{OR}]=2.875$ ) compared to those with no friends who smoke, when the other factors in the model were held constant. Siblings who smoke were also an important predictive factor, with pupils whose siblings smoke being 2.2 more likely to smoke $(\mathrm{OR}=2.222)$. The model with these predictors was statistically significant $\left(\chi^{2}(14)\right.$ $=418.02, \mathrm{P}<0.001)$, which indicates that it can distinguish between pupils who smoke and pupils who do not.

The strongest predictor of occasional alcohol consumption in high quantities among the pupils was male gender, with boys being 5.2 times more likely to adopt such a behavior $(\mathrm{OR}=5.148)$ than girls. Additionally, siblings' binge drinking was an important predictor, with pupils whose siblings binge drink being 1.7 times more likely to adopt the behavior $(\mathrm{OR}=1.723)$. Lastly, friends' binge drinking was also a significant predictor, as pupils with such friends were 1.5 times more likely to adopt the behavior $(\mathrm{OR}=1.519)$. The model was statistically significant $\left(\chi^{2}(18)=291.59, \mathrm{P}<0.001\right)$, which indicates that it can distinguish between pupils who occasionally consume alcohol in high quantities and pupils who do not. 


\section{Discussion}

In our study, the following factors related to family members and friends and the living environment were identified. First, there were issues with the relationships with parents among some pupils, with $23.2 \%$ being neither satisfied nor unsatisfied and $4.9 \%$ being unsatisfied. Second, there were also issues regarding some pupils' satisfaction with the financial situation of their family, with $21.8 \%$ being neither satisfied nor unsatisfied and $16.4 \%$ being unsatisfied. Regarding satisfaction with relationships with schoolmates, $59.2 \%$ were satisfied, while only $7.7 \%$ were unsatisfied. Lastly, regarding satisfaction with relationships with friends, $80.2 \%$ were satisfied, while only $1.8 \%$ were unsatisfied.

\section{Family}

During adolescence, the direct influence of parents is surpassed by the influence of friends. Thus, family risk factors, including the influence of antisocial parents, poor economic status, and other risk factors with high influence during childhood, decrease in importance. ${ }^{14,15}$ Poor-quality relationships between parents and teenagers involve inappropriate monitoring of the teenagers' activities and lack of discipline. ${ }^{6,16}$ Broken homes and parental abuse also have small effects. During adolescence, parents can have an indirect influence, because the type of friends chosen by a young person depends on the relationship that the young person has with his/her parents. ${ }^{17}$ A study by Ku L et al ${ }^{18}$ revealed that teenagers that came from single-parent families had significantly more frequent health-related risk behaviors compared to teenagers from families with two parents (except for suicidal thoughts and suicide attempts, for which there were no significant differences). The associations were particularly strong for smoking, risky sexual behaviors, and alcohol consumption among the teenagers.

Eaton DK et al ${ }^{19}$ found that higher family income and a higher employment rate among teenagers were associated with lower risks of unwanted pregnancies among teenagers. A study conducted in the $\mathrm{USA}^{20}$ revealed that the prevalence of participation in violent events was higher among teenagers who came from low-income families compared to those who came from high-income families, irrespective of age or gender.

\section{School}

As compared to childhood, an indifferent attitude toward school performance, especially in cases where this can lead to school problems, is a highly important risk factor. Children exposed to violence in the educational environment often choose to play truant or to bring guns into school to protect themselves. ${ }^{21-23}$

\section{Friend Group}

An individual's friend group can have a great deal of influence on young people. Teenagers who have few or weak social connections, do not follow conventional social activities, are unpopular, and are at risk of becoming violent. $^{24,25}$ Another alt risk factor is belonging to a gang. Researchers who studied the reasons why children join a gang have discovered that the risk factors are identical to the risk factors for violent behavior. ${ }^{26}$ Some researchers theorized that a gang might work as a surrogate for young people who have weak connections with their families. ${ }^{8}$

In a study by Parker and Asher ${ }^{27}$ on the quality of relationships with friends and the degree of satisfaction with relationships with friends, young people who had difficulty being accepted had fewer friends and they were satisfied with their relationship with these friends. These young people had a lower relationship quality compared to other teenagers. Having at least one friend, quality of friendship, and group acceptance were independent predictors of decreased loneliness. Correlations between the subscales of friendship quality and relationship satisfaction have shown that positive qualities of friendship (care, comradeship and relaxation, help and guidance, and intimate exchanges) are associated with increased satisfaction with relationships.

Family context, mental health issues were associated with distant relationships with parents, and family violence, while the school context, feelings of loneliness and trouble sleeping were associated with poor peer relationships, insecurity at school. ${ }^{27}$

The influence of school factors on student's well-being is most of the times low, but teacher's support promote positive school climates which important in reducing bullying. ${ }^{28}$

We consider a strength point the following facts:1) a great percentage of the pupils come from organized families, 2) most pupils are satisfied with their parents, 3) $80 \%$ are satisfied with their relationships with friends.

The weak points of the results of the study are that: 1) only $59.2 \%$ of the pupils are satisfied with their relations with schoolmates, 2) the predictive models among pupils will influence the majority almost three time more to start 
smoking. Although these points seem weak, we still consider that we found the weak points and therefore can find ways to strengthen them.

We consider a constriction the fact that less than 50\% pupils are satisfied with their financial status of their families.

Therefore mental health during adolescence can affect individual's long-term quality of life, family and school contexts can influence mental health.

These results, help to highlight potential points of intervention for supporting public health programs within the boarding-school student population. ${ }^{29}$

In conclusion we emphasize the need to inform population about the potentially adverse consequences associated with violence against children. ${ }^{30,31}$

\section{Conclusions}

In our study, $79.2 \%$ of the pupils came from an organized family, $13.2 \%$ came from a disorganized family, and $7.6 \%$ came from a reorganized family.

$71.1 \%$ of the pupils reported being satisfied with their relationship with their parents, while $4.9 \%$ were unsatisfied. Girls were significantly more unsatisfied with their relationship with their parents than boys. $46.2 \%$ were satisfied with the financial status of their families, while $16.4 \%$ were unsatisfied. Girls were significantly more unsatisfied with the financial status of their family than boys. $59.2 \%$ of the pupils were satisfied with their relationship with their schoolmates and only $7.7 \%$ were unsatisfied. Boys were significantly more satisfied than girls with their relationship with their schoolmates. $80.2 \%$ were satisfied with their relationship with their friends, while only $1.8 \%$ were unsatisfied. Boys were significantly more satisfied than girls with their relationship with friends. For both genders, relationships with friends generated significantly more satisfaction than relationships with schoolmates.

The predictive model of pupils' smoking status identified the following moderate predictors (OR of 2-3): high number of friends who smoke $(\mathrm{OR}=2.875)$ and smoking status of siblings $(\mathrm{OR}=2.222)$. The major predictor in the model of occasional alcohol consumption in high quantities by pupils was male gender $(\mathrm{OR}=5.148)$.

\section{Acknowledgments}

We are particularly grateful to all the people who have given us help on our article.

\section{Disclosure}

The authors are affiliated with "V. Babes" University Medicine and Pharmacy from Timisoara (as researchers and teachers), as well as employers of Timisoara County Hospital or Public Health Department and Center for Studies in Preventive Medicine-accredited by "V. Babes" University of Medicine and Pharmacy from Timisoara.

The research results can be used as material by each member with the acceptance of all the other members, coauthors.

We also attach the ethic statement of the research, from the Commission for Scientific Research Ethics of "V. Babes" University of Medicine and Pharmacy Timisoara.

No funding was available for this study. The authors have no commercial relationship or potential conflicts of interests of any nature related to this manuscript.

\section{References}

1. Cosmovici A. General Psychology. Iaşi: Polirom Publishing House; 1996.

2. Eibl E. Human agressivity. Trei Romcart Publishing House Buchrest; 1995.

3. Ferreol G, Neculau A. Violence, psychosocial aspects. Iaşi: Polirom Publishing House; 2003.

4. Gerber R. Vibrationl medicine, Elite Polirom Publishing House Buchrest; 2005.

5. Luban-Plozza B, Bradu Iamandescu I. Psychosocial dimension of medical practice. Infomedica Publishing House Bucharest; 2003.

6. Băcean CO, Toma M. Psyhic stress and agressivity in adolescents. J Hygiene Public Health. 2008;58(4):98-103.

7. World Health Organization. The world health report 2004: changing history. Geneva: World Health Organization; 2004.

8. Loeber R, Farrington DP, Waschbusch DA. Serious and violent juvenile offenders. In: Loeber R, Farrington DP, editors. Serious and Violent Juvenile Offenders: Risk Factors and Successful Interventions. Thousand Oaks:Sage Publications; 1998. Vol. 25. 4:374-375.

9. Ursoniu S, Putnoky S, Vlaicu B. Body weight perception high school students and its influence on weight management behaviors in normal weight students: a cross-sectional study. Wien Klin Wochenschr. 2010;123(11-12):327-333. doi:10.1007/s00508-011-1578-3

10. Center for Disease Control and Prevention. The youth risk behavior surveillance system. US Department of Health and Human Services; 2005. Available from: https://www.cdc.gov/healthyyouth/data/yrbs/ index.htm. Accessed May 4, 2021.

11. Bagiu IC, Vlaicu B, Onisei D, et al. Types of alcohol associated to binge drinking behaviour among students from Timis county. Revista De Chimie Bucuresti. 2016;67(9):1684-1687.

12. Popa MD, Cheveresan A, Dobrescu A, et al. Time trends regarding the association between drug and tobacco consumption among students from the west part of Romania. A transversal population study. Revista De Chimie Bucuresti. 2019;69(1):118-120. doi:10.37358/ RC.19.1.6863

13. Fergusson DM, Boden JM, Horwood LJ. Exposure to single parenthood in childhood and later mental health, educational, economic, and criminal behavior outcomes. Arch Gen Psychiatry. 2007;64 (9):1089-1095. doi:10.1001/archpsyc.64.9.1089 
14. Im Y, Oh WO, Suk M. Risk Factors for suicide ideation among adolescents: five-year national data analysis. Arch Psychiatr Nurs. 2017;31:282-286. doi:10.1016/j.apnu.2017.01.001

15. Hawkins JD, Herrenkohl TL, Farrington DP, et al. A review of predictors of youth violence. In: Loeber R, Farrington DP, editors. Serious and Violent Juvenile Offenders: Risk Factors and Successful Intervention. Thousand Oaks: Sage Publications; 1998.

16. Romoşan F, Şerban C, Tuţă-Sas I. Capitol 1, adultul tânăr. In: Vlaicu B, editor. Comportamente Cu Risc La Studenţii Din Judeţul Timiş. Timişoara: Editura Eurobit; 2009:5-19.

17. Blum RW, Beuhring T, Shew M, et al. The effects of race/ethnicity, income, and family structure on adolescent risk behaviors. Am J Public Health. 2000;90(12):1879-1884.

18. Ku L, Sonenstein FL, Pleck JH. Neighborhood, family, and work: influences on the premarital behaviors of adolescent men. Soc Forces. 1993;72(2):479-503. doi:10.2307/2579858

19. Eaton DK, Kann L, Kinchen S, et al. Youth risk behavioral surveillance-United States, 2007. MMWR Surveillance Summaries. 2008;57(SS04):1-131.

20. Brener ND, Simon TR, Krug EG, Lowry R. Recent trends in violence-related behaviors among high school students in the United States. JAMA. 1999;282(5):440-446. doi:10.1001/ jama.282.5.440

21. Laub JH, Lauritsen JL. The interdependece of school violence with neighborhood and family conditions. In: Elliott DS, Hamburg BA, Williams KR, editors. Violence in American Schools: A New Perspective. Cambridge: Cambridge University Press; 1998:127-156.

22. Snyder HN, Sickmund M. Juvenile Offenders and Victims: 1999 National Report. Washington, DC: Office of Juvenile Justice and Delinquency Prevention; 1999.

23. Baggea C, Shera KJ. Adolescent alcohol involvement and suicide attempts: toward the development of a conceptual framework. Clin Psychol Rev. 2008;28(8):1283-1296. doi:10.1016/j.cpr.2008.06.002
24. Aseltine RH, Schilling EA, James A, et al. Age variability in the association between heavy episodic drinking and adolescent suicide attempts: findings from a large-scale, school-based screening program. J Am Acad Child Adolesc Psychiatry. 2009;48 (3):262-270. doi:10.1097/CHI.0b013e318195bce8

25. Measure DHS. STATcompiler, Calverton: Macro International; 2007. Available from: http://www.measuredhs.com. Accessed February 15, 2021.

26. Parker GJ, Asher SR. Friendship and friendship quality in middle childhood: links with peer group acceptance and feelings of loneliness and social dissatisfaction. Develop Psychol. 1993;29:611-621. doi:10.1037/0012-1649.29.4.611

27. Escobar. Family and school context: effects on the mental health of brazilian students. Int J Environ Res Public Health. 2020;17:6042. doi:10.3390/ijerph17176042

28. Govorova E, Benítez I, Muñiz J. Predicting student well-being: network analysis based on PISA 2018. Int J Environ Res Public Health. 2020;17:4014. doi:10.3390/ijerph17114014

29. Noll, Noll M, Noll PRES, et al. Health-risk behavior differences between boarding and non-resident students: adolescent National School Health Survey. Arch Public Health. 2020;78:8. doi:10.1186/ s13690-020-0392-7

30. Ssenyonga J, Magoba Muwonge C, Hecker T. Prevalence of family violence and mental health and their relation to peer victimization: a representative study of adolescent students in Southwestern Uganda. Child Abus Negl. 2019;98:104194. doi:10.1016/j. chiabu.2019.104194

31. Hibell B, Ansersson B, Bjarnason T, et al. The ESPAD Report 2003 Alcohol and Other Drug Use Among Students in 35 European Countries. Stockholm: The Swedish Council for Information on Alcohol and Other Drugs; 2004.
Psychology Research and Behavior Management

\section{Publish your work in this journal}

Psychology Research and Behavior Management is an international, peer-reviewed, open access journal focusing on the science of psychology and its application in behavior management to develop improved outcomes in the clinical, educational, sports and business arenas. Specific topics covered in the journal include: Neuroscience, memory and decision making; Behavior modification and management; Clinica applications; Business and sports performance management; Social and developmental studies; Animal studies. The manuscript management system is completely online and includes a very quick and fair peer-review system, which is all easy to use. Visit http://www. dovepress.com/testimonials.php to read real quotes from published authors. 